\title{
PENGEMBANGAN BAHAN AJAR INTERAKTIF BERBASIS E-LEARNING UNTUK MENINGKATKAN HASIL BELAJAR MAHASISWA
}

Oleh :

\author{
*Adek Nilasari Harahap ${ }^{1}$, Jainal Abidin ${ }^{2}$ \\ 1.Fakultas Keguruan dan Ilmu Pendidikan, Universitas Graha Nusantara Padangsidimpuan \\ 2.Fakultas Teknik, Universitas Graha Nusantara Padangsidimpuan
}

\begin{abstract}
Abstrak
Bahan ajar interaktif matematika berbasis e-learning merupakan sarana pembelajaran matematika yang dapat digunakan oleh pendidik untuk membantu peserta didik dalam proses pembelajaran dengan menggunakan elektronik seperti handphone dan komputer. Bahan ajar tersebut juga membantu pembelajaran pendidik dan peserta didik di luar sekolah dan saat jarak jauh. Metode penelitian yang digunakan adalah Research and Development $(R \& D)$ berdasarkan model penelitian dan pengembangan 4D. Tahapan yang dilakukan yaitu tahap pendefinisian (define), tahap perencanaan (design), tahap pengembangan (develop), dan tahap penyebaran (disseminate). Hasil validasi bahan ajar yang diperoleh pada aspek kelayakan isi 3,58, aspek kebahasaan 3,67 dan untuk aspek kelayakan penyajian 3,53. Hasil belajar mahasiswa berasal dari nilai pre-test dan post-test. Nilai rata-rata mahasiswa pada kegiatan pre test diperoleh sebesar 40,25, sedangkan untuk post test sebesar 82,19.
\end{abstract}

Kata kunci-Pengembangan, Bahan Ajar Interaktif, E-Learning, Hasil Belajar

\begin{abstract}
E-learning-based interactive mathematics teaching materials are a means of learning mathematics that can be used by educators to assist students in the learning process using electronics such as mobile phones and computers. The teaching materials also help educators and students learn outside of school and at a distance. The research method used is Research and Development $(R \& D)$ based on the $4 D$ research and development model. The stages carried out are the defining stage, the planning stage (design), the development stage (develop), and the dissemination stage (disseminate). The results of the validation of teaching materials obtained on the feasibility aspect of the content are 3.58, the linguistic aspect is 3.67 and for the presentation feasibility aspect is 3.53. Student learning outcomes come from the pre-test and post-test scores. The average score of students in the pre-test activity was 40.25, while the post-test was 82.19 .
\end{abstract}

Keywords - Development, Interactive Teaching Materials, E-Learning, Learning Outcomes

\section{PENDAHULUAN}

Di era globalisasi seperti saat ini, tidak dapat dipungkiri bahwa pendidikan merupakan kebutuhan pokok dalam kehidupan seseorang, dikarenakan dapat mengembangkan potensi yang ada pada dirinya melalui proses pembelajaran, sehingga mampu dalam memenuhi kebutuhan hidupnya. Sejatinya seorang dosen mempunyai usaha dalam mendidik mahasiswanya agar tujuan pendidikan yang diinginkan tercapai.

Menurut Oemar Hamalik (2009), pendidikan adalah suatu proses dalam rangka mempengaruhi peserta didik agar dapat menyesuaikan diri sebaik mungkin dengan lingkungannya, dengan demikian akan menimbulkan perubahan dalam dirinya yang memungkinkannya untuk berfungsi secara dekat dalam kehidupan masyarakat. Pelaksanaan pembelajaran merupakan bagian dari salah satu faktor yang berpengaruh terhadap usaha-usaha untuk mencapai tujuan-tujuan dari pendidikan. Pengembangan pribadi mahasiswa merupakan tujuan akhir pendidikan pada umumnya.

Hao Shi (2010) mengatakan pengembangan suatu bahan ajar dilakukan untuk memberikan pembelajaran konteks dimana mahasiswa dapat merefleksikan materi pembelajaran yang baru, membahas pemahaman tentatif mereka dengan orang lain atau temannya, aktif mencari informasi terbaru, 
mengembangkan keterampilan dalam komunikasi dan kolaborasi, serta membangun koneksi konseptual dalam basis pengetahuan yang telah ada.

Mahasiswa perlu memiliki pengetahuan matematika yang sangat cukup untuk menghadapi masa depan. Proses pembelajaran matematika yang dilakukan pada umumnya masih menempatkan mahasiswa sebagai objek, sedangkan dosen bertindak sebagai sumber ilmu dan keterampilan. Dosen merupakan faktor terpenting untuk menentukan keberhasilan pembelajaran. Menentukan bahan ajar menjadi bagian pokok yang harus dikerjakan oleh seorang Dosen. Penggunaan bahan ajar yang kurang sesuai sangat berpengaruh terhadap pelaksanaan proses pembelajaran dan hasil belajar mahasiswa.

Dari beberapa mata kuliah wajib yang harus ditempuh mahasiswa pendidikan matematika salah satunya adalah evaluasi proses dan hasil belajar. Mata kuliah ini mempelajari berbagai hal yang berkaitan dengan teknik penilaian baik selama proses pembelajaran maupun di akhir pembelajaran, misalnya menyusun kisi-kisi soal dan analisis butir soal yang akan digunakan dalam pembelajaran. Kemampuan melakukan evaluasi hasil belajar merupakan kemampuan dasar yang harus dikuasai oleh para mahasiswa sebagai calon guru.

Sebagai dosen pengampu mata kuliah evaluasi hasil belajar ditemukan beberapa hal yang dialami oleh mahasiswa antara lain :

1. Mahasiswa masih bingung dalam menentukan nilai reabilitas serta termasuk kategori sangat rendah, rendah, sedang, tinggi, atau sangat tinggi.

2. Belum maksimalnya mahasiswa dalam menggunakan handphone android dan laptop dalam pembelajaran.

3. Belum adanya bahan ajar matakuliah evaluasi hasil belajar yang dimiliki FKIP Universitas Graha Nusantara yang dapat digunakan mahasiswa pendidikan matematika serta dapat dipakai juga oleh mahasiswa prodi lainnya.

4. Rendahnya nilai rata-rata hasil belajar mahasiswa yaitu $<60$, sehigga perlu adanya cara yang dilakukan untuk meningkatkan hasil belajar mahasiswa.

5. Mahasiswa masih mengalami kesulitan dalam mengolah data hasil belajar yang diperoleh saat penelitian dikarenakan terbatasnya waktu pada saat perkuliahan evaluasi hasil belajar.

6. Berdasarkan hal tersebut, maka diperlukan suatu bahan ajar sehingga membantu mahasiswa dan dosen.

Dari hal-hal yang ditemukan di atas, maka dibutuhkan suatu bahan ajar yang dapat membantu mahasiswa dan dosen dalam proses perkuliahan. Dengan adanya bahan ajar dapat membantu mahasiswa untuk meningkatkan kemampuan mahasiswa dalam memahami materi, agar mahasiswa dapat belajar secara mandiri dan menyesuaikan dengan teknologi. Bahan ajar berbasis $e$-learning tidak mengharuskan dosen membimbing mahasiswa secara satu persatu, namun sesama mahasiswa saja dapat saling membantu.

Matsuda (2016), mengatakan bahwa bahan ajar e-learning dikembangkan harus bisa memberikan kepercayaan diri berpikir terhadap mahasiswa, "Aku bisa melaksanakannya". Dosen dapat membimbing mahasiswa dan memberitahukan prosedur pembelajaran. Bahan ajar berbasis e-learning juga sebagai pengganti fungsi dosen dikarenakan mahasiswa dapat saling sharing di sosial media, baik dalam bentuk aplikasi maupun web.

Dosen bertugas dalam menjelaskan saat pembelajaran, maka bahan ajar berbasis e-learning juga harus mampu memperjelas pembelajaran tersebut dengan bahasa yang mudah diterima mahasiswa seperti halnya seperti dosen. Dengan adanya e-learning, pembelajaran lebih simpel dan terbuka. Pembelajaran $e$ learning bisa dilakukan dimana saja, kapan saja, dan dengan siapa saja kita ingin mempelajarinya. Penelitian pengembangan ini memiliki tujuan sebagai berikut: 1) Bahan ajar berbasis $e$ - learning dapat menunjang pembelajaran pada matakuliah evaluasi hasil belajar. 2) Meningkatkan hasil belajar mahasiswa dengan penerapan bahan ajar berbasis e-learning.

\section{METODE PENELITIAN}

Penelitian ini dilaksanakan Universitas Graha Nusantara Padangsidimpuan Fakultas Keguruan dan Ilmu Pendidikan (FKIP). Yang menjadi subjek dalam penelitian ini adalah mahasiswa semester VI program studi Pendidikan Matematika. Sedangkan objek penelitian adalah bahan ajar berbasis e-learning yang akan digunakan pada matakuliah evaluasi hasil belajar matematika.

Penelitian ini menggunakan metode penelitian pengembangan (Research and Development), merupakan penelitian yang digunakan untuk menghasilkan suatu produk tertentu serta menguji keefektifan produk yang dibuat tersebut. Penelitian pengembangan mengacu pada model pengembangan 
bahan ajar 4-D (four-D Model), terdiri dari empat tahapan yaitu tahap pendefinisian (define), tahap perancangan (design), tahap pengembangan (develop), dan tahap penyebaran (disseminate).

Yang menjadi instrumen dalam penelitian berupa lembar validasi bahan ajar e-learning dan tes hasil belajar dalam bentuk post-test dan pre-test. Adapun urutan dari langkah-langkah penelitian yang akan dilakukan untuk mendapatkan data penelitian tersebut adalah:

a. Menyiapkan bahan ajar matakuliah Evaluasi Hasil Belajar Matematika

b. Memvalidasikan bahan ajar. Bahan ajar divalidasi oleh 3 orang validator.

c. Merevisi bahan ajar yang telah divalidasi ketiga validator.

d. Melakukan uji coba bahan ajar kepada mahasiswa.

e. Memberikan angket berisi respon mahasiswa terhadap bahan ajar.

f. Melakukan revisi terhadap bahan ajar dari hasil angket mahasiswa.

Analisis data dilakukan setelah angket selesai divalidasi oleh 3 orang validator yang terdiri dari 2 orang validator ahli matematika, 1 ahli dalam bahasa. Bahan ajar interaktif matematika berbasis $e$ - learning memiliki 4 pilihan jawaban yang disesuaikan dengan pertanyaannya. Masing-masing pilihan jawaban memiliki skor berbeda-beda, yang mengartikan besarnya tingkatan-tingkatan validasi bahan ajar interaktif matematika berbasis $e$-learning. Skor penilaian dari tiap pilihan jawaban dapat dilihat pada tabel berikut:

Tabel 1. Kriteria Jawaban Item Instrumen Validasi Beserta Skornya

$\begin{array}{ccc}\text { No } & \text { Jawaban } & \text { Skor } \\ 1 & \text { Sangat baik } & 4 \\ 2 & \text { Cukup baik } & 3 \\ 3 & \text { Kurang baik } & 2 \\ 4 & \text { Tidak baik } & 1\end{array}$

Dari skor hasil penilaian dari masing-masing validator, baik dari ahli materi maupun ahli bahasa tersebut akan dicari rata-ratanya yang kemudian dikonversikan ke dalam pertanyaan-pertanyan untuk menentukan kevalidan dan kelayakan bahan ajar interaktif matematika berbasis e-learning tersebut. Pengkonversian nilai skor menjadi sebuah penilaian dapat dilihat dalam tabel 2.

Tabel 2. Kriteria Validasi

$\begin{array}{ccc}\text { Skor Kualitas } & \text { Kriteria kelayakan } & \text { Keterangan } \\ 3,26<-\leq 4,00 & \text { Valid } & \text { Tidak Revisi } \\ 2,51<\leq \leq 3,26 & \text { Cukup Valid } & \text { Revisi Sebagian } \\ 1,76<-\leq 2,51 & \text { Kurang Valid } & \text { Revisi Sebagian dan Pengkajian Ulang Materi } \\ 1,00<\leq 1,76 & \text { Tidak Valid } & \text { Revisi Total }\end{array}$

Sedangkan untuk melihat besarnya peningkatan hasil belajar mahasiswa sebelum diberikan bahan ajar dengan sesudah diberikan bahan ajar dihitung dengan menggunakan analisis kuantitatif dengan rumus:

$$
g=\frac{\text { post test }- \text { pre test }}{\text { nilai maksimum - pre test }}
$$

Setelah hasil belajar mahasiswa selesai dianalisis, tahap selanjutnya yang dilakukan adalah mengkategorikannya sesuai dengan tabel berikut:

\section{Tabel 3. Kategori n-Gain}

$\begin{array}{cc}\text { Interval } & \text { Kategori } \\ G \geq 0,7 & \text { Tinggi } \\ 0,7>G \geq 0,3 & \text { Sedang } \\ G<0,3 & \text { Rendah }\end{array}$

\section{HASIL DAN PEMBAHASAN}

Bahan ajar yang dikembangkan mendapat penilaian dari ahli validator bidang materi, yakni dua validator dosen dari prodi Pendidikan Matematika sendiri yaitu Ibu Nurdalilah, S.Si.,M.Pd dan Ibu Susi Sulastri Lubis, S.Pd., M.P.Mat dan satu ahli bahasa merupakan dosen dari prodi Pendidikan Bahasa Inggris Ibu Siti Meutia Sari, S.Pd.,M.Si. Validasi dilaksanakan dalam dua tahapan hingga bahan ajar dinyatakan kevalidan dan kelayakannya untuk uji coba. Penskoran dari ahli materi dan ahli bahasa ada tiga aspek yakni kelayakan isi, kebahasaan, dan kelayakan penyajian bahan ajar. 
Validasi tahap 1 pada aspek kelayakan isi memperoleh skor rata-rata sebesar 2,79 termasuk kriteria cukup valid, aspek kebahasaan memperoleh skor rata-rata sebesar 2,75 termasuk kriteria cukup valid, sedangkan aspek kelayakan penyajian memperoleh skor rata-rata sebesar 2,73 dengan kriteria cukup valid. Jumlah rata-rata dari keseluruhan aspek tentang kelayakan materi memperoleh skor sebesar 2,77 yang termasuk kriteria cukup valid. Berdasarkan hasil validasi kelayakan materi dan bahasa pada bahan ajar interaktif matematika berbasis e-learning masih perlu melakukan revisi sesuai dengan saran dan masukan validasi tahap 1 .

Produk bahan ajar interaktif setelah selesai direvisi berdasakan saran dari setiap ahli materi dan bahasa, maka langkah selanjutnya adalah melakukan validasi tahap 2. Pada validasi tahap 2 setiap aspek memperoleh skor rata-rata, aspek kelayakan isi memperoleh nilai rata-rata 3,58 dengan kriteria valid, aspek kebahasaan memperoleh nilai 3,67 yang merupakan kriteria valid, dan untuk aspek kelayakan penyajian mendapatkan nilai 3,53 yang termasuk kriteria valid.

Nilai rata-rata dari setiap aspek dihitung keseluruhannya yang berhubungan dengan kelayakan materi dan bahasa, sehingga mendapatkan skor rata-rata 3,59 yang merupakan kriteria valid yang berarti tidak ada perbaikan dan bisa digunakan sebagai bahan ajar. Skor yang didapatkan dari validasi tahap 2 lebih meningkat dari pada validasi tahap 1, sehingga hasil kelayakan materi dan bahasa dari produk bahan ajar termasuk pada kriteria "valid" dan layak uji coba tanpa revisi.

Dalam uji pengembangan hasil belajar mahasiswa pada matakuliah Evaluasi Hasil Belajar dengan menggunakan bahan ajar berbasis e-learning diukur dengan menggunakan hasil pre-test dan post- test mahasiswa pada awal pertemuan awal dan pertemuan terakhir saat perkuliahan berlangsung. Data hasil belajar mahasiswa tersebut dapat dilihat pada tabel berikut:

$\begin{array}{|ccc|}\text { Kegiatan } & \begin{array}{c}\text { Tabel 4. Analisis hasil belajar mahasiswa } \\ \text { Rata-rata nilai } \\ \text { mahasiswa }\end{array} & \begin{array}{c}\text { Persentasi Hasil } \\ \text { Belajar }\end{array} \\ \text { Pre - Test } & 40,25 & 40 \% \\ \text { Post - Test } & 82,19 & 83 \%\end{array}$

Nilai rata-rata mahasiswa pada kegiatan pre test diperoleh sebesar 40,25, sedangkan untuk post test sebesar 82,19. Dari data tersebut dapat dikatakan bahwa peningkatan hasil belajar mahasiswa rata- rata mengalami kenaikan sebesar 43\%. Peningkatan tersebut sudah "cukup baik". Pada kegiatan pre-test hanya 3 siswa yang dinyatakan tuntas, dan sebanyak 20 siswa tidak tuntas. Namun pada kegiatan post-test sebanyak 16 siswa dinyatakan tuntas. Meskipun peningkatannya hanya sebesar $43 \%$, namun pembelajaran dengan menggunakan bahan ajar interaktif berbasis e-learning dapat dikategorikan "cukup baik".

Sedangkan dari hasil wawancara doesen dengan mahasiswa terhadap bahan ajar yang digunakan pada saat uji coba kelompok kecil dan kelompok besar berlangsung diketahui mahasiswa senang menggunakan bahan ajar interaktif matematika berbasis e-learning, karena bahan ajar mudah digunakan, mudah untuk memahami pokok materi dan suasana belajar baru bagi mereka. Bahan ajar dapat digunakan di luar sekolah melalui handphone, laptop maupun komputer yang bisa dibuka ulang dengan mudah dan bisa berkomunikasi dengan temannya, secara tidak langung akan sangat membantu proses pembelajaran mahasiswa kapan dan dimana saja. Hal tersebut sesuai dengan pendapat Nanang (2015), bahwa keterampilan dan pengetahuan lebih mudah didapatkan dan dipelajari ulang dengan menggunakan bantuan komputer sehingga bisa dengan mudah terselesaikannya masalah yang diberikan.

\section{KESIMPULAN}

Berdasarkan hasil analisis data yang diperoleh, maka dapat diambil kesimpulan bahwa validasi bahan ajar interaktif berbasis e-learning telah dilakukan tahap validasi oleh para ahli dibidangnya dengan hasil valid dengan nilai validasi yang diperoleh yakni pada aspek kelayakan isi 3,58, aspek kebahasaan 3,67 dan untuk aspek kelayakan penyajian 3,53. Hasil belajar mahasiswa berasal dari nilai pre-test dan post-test, kemudian akan didapatkan peningkatan hasil belajar siswa. Setelah menggunakan bahan ajar interaktif berbasis e-learning pada matakuliah evaluasi hasil belajar, dapat disimpulkan bahwa peningkatan hasil belajar mahasiswa dalam kategori sedang dimana peningkatan rata-rata hasil belajar siswa sebesar $43 \%$. Bahan ajar interaktif matematika berbasis e-learning diharapkan dapat menjadi motivasi kepada mahasiswa untuk belajar secara mandiri. Peneliti juga mengharapkan mahasiswa bisa memanfaatkan 
bahan ajar untuk proses pembelajaran di luar sekolah, dengan kata lain mahasiswa juga bisa lebih luas mengetahui manfaat elektronik dalam pembelajaran.

\section{REFERENSI}

Akbar, S. 2013. Instrumen Perangkat Pembelajaran. Bandung: PT Remaja Rosdakarya.

Daryanto, \& Cahyo, A. D. (2014). Pengembangan Perangkat Pembelajaran (Silabus, RPP, PHB, Bahan Ajar). Yogyakarta: Gava Media.

Hamalik, O. (2009). Kurikulum dan Pembelajaran. Jakarta: PT Bumi Aksara.

Hao Shi. 2010. Developing E-Learning Materials For Software Development Course. International Journal Of Managing Information Technology. Vol 2 (No 2) Hal. 16-21. Diakses tanggal 5 Juni 2021 pada https://pdfs.semanticscholar.org/9472/e510ce89107e60cfd6131d5d.pdf.

Harahap, A. N., \& Lubis, S. S. (2021). Upaya Meningkatan Self Confidence Mahasiswa Dengan Menggunakan Metode Inquiry Pada Matakuliah Aljabar Linier Elementer Universitas Grahaa Nusantara Padangsidimpuan. EKSAKTA: Jurnal Penelitian dan Pembelajaran MIPA, 6 (1), 118124.

Majid, A. (2011). Perencanaan Pembelajaran. Bandung: PT Remaja Rosda Karya.

Matsuda. 2016. Development And Evaluation Of The E-Learning Teaching Materials for surgical nursing training. US National Library. Vol 1 (No 3) Hal. 122-123. Diakses tanggal 3 Juni 2021 pada https://www.ncbi.nlm.nih.gov/pubmed/17102396.

Nurdalilah, N., \& Arifitriana, W. (2019). Pengembangan Bahan Ajar Analisis Real Berbasis Konstruktivisme Pada Program Studi Pendidikan Matematika Universitas Graha Nusantara. Jurnal ESTUPRO, 4(3), 22-37.

Supriadi, N. (2015). Pembelajaran Geometri Berbasis GeoGebra sebagai Upaya Meningkatkan Kemampuan Komunikasi Matematis. Al-Jabar: Jurnal Pendidikan Matematika , 105.

Trianto. 2010. Mendesain Model Pembelajaran Inovatif-Progresif. Jakarta: Kencana Prenada Media Group. 